\title{
Comparison of the effect of Davis instructional strategy and traditional instructional on the development of reading skills of dyslexic boys in grade 2 of elementary school from Roshtkhar
}

\author{
Mohsen Khoshroo ${ }^{1}$, Ali Mohammad Rezaei², Siavash Talepasand ${ }^{3}$ \\ 1-M.A Educational Psychology, Department of Educational Psychology, Semnan University, Semnan, Iran. \\ 2- Associate Professor, Department of Educational Psychology, Semnan University, Semnan, Iran (Corresponding \\ Author). $\quad$ E-mail: rezaei_am@semnan.ac.ir \\ 3- Associate Professor, Department of Educational Psychology, Semnan University, Semnan, Iran.
}

Received: 07/10/2020

Accepted: 20/12/2020

\begin{abstract}
Introduction: Reading is one of the most important skills in elementary school so that its disorder affects learning of other subjects.

Aim: This study aimed to compare the effect of Davis educational strategy with traditional education in improving the reading of dyslexic male students in the second grade of elementary school.

Method: The research type was quasi-experimental. The population of this study included all boys in grade 2 of elementary school from Rashtkhar city in the academic year 2015-2016 that 10 of them who were dignosed with dyslexia, were randomly selected based on a checklist of 27 items for dyslexia symptoms, report card and health assessment card of the first year of elementary school. Then these students were randomly divided in experimental group with davis method intervention and the other group with traditional instruction. After Davis instructional intervention, post-test was performed on both groups and obtained data from pre-test and posttest were analyzed using SPSS version 19 with Kolmogorov-Smirnov test and dependent t-test.

Results: The results of dependent t-test and difference between scores of the two groups showed that improvement mean in Davis group (8.15) compared to the traditional group (2.67) was significantly different, which indicates the effect of Davis treatment intervention on improving students' reading $(\mathrm{P}<0.01)$.
\end{abstract}

Conclusion: It can be concluded that Davis method has improved students reading skills by increasing the range of precision and attention, improving visual memory and comprehension.

Keywords: Reading, Dyslexia, Davis method, Traditional method

\footnotetext{
How to cite this article : Khoshroo M, Rezaei AM, Talepasand S. Comparison of the effect of Davis instructional strategy and traditional instructional on the development of reading skills of dyslexic boys in grade 2 of elementary school from Roshtkhar. Shenakht Journal of Psychology and Psychiatry. 2021; 7 (6): 43-52 .URL: http://shenakht.muk.ac.ir/article-1-768-en.pdf
}

Copyright ( $\odot 2018$ the Author (s). Published by Kurdistan University of Medical Sciences. This is an open access article distributed under the terms of the Creative Commons Attribution-Non Commercial License 4.0 (CCBY-NC), where it is permissible to download, share, remix, transform, and buildup the work provided it is properly cited. The work cannot be used commercially without permission from the journal. 


\title{
مقايسه تأثير راهبرد آموزشى داويس و آموزش سنتى بر ييشرفت مهارتهاى خواندن دانش آموزان يسر نار ساخوان در هايه دوم دبستان شهر ستان رشتخوار
}

\author{
محسن خوشرو'، على محمد رضايى '، سياوش طالع پِندَّ \\ ا. كارشناس ارشد روانشناسى تربيتى، كروه روان شناسى تربيتى، دانشكاه سمنان، سمنان، ايران.
}

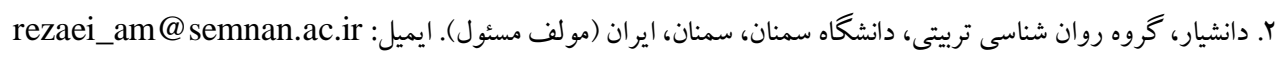
r. أشيار، گروه روان شناسى تربيتى، دانشخاه سمنان، سمنان، ايران.

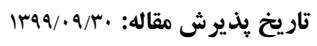

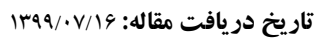

جكيده

مقدمه: مهارت خواندن يكى از مهمترين مهارتها در دوره ابتدايى است به طورى كه اختلال در آن بر يادگيرى ساير دروس تأثير مى كذارد.

هدف: هدف يُزوهش حاضر، مقايسه تأثير راهبرد آموزشى داويس با آموزش سنتى در بهبود خواندن دانش آموزان پِر نارسا خوان بايه دوم ابتدايى بود.

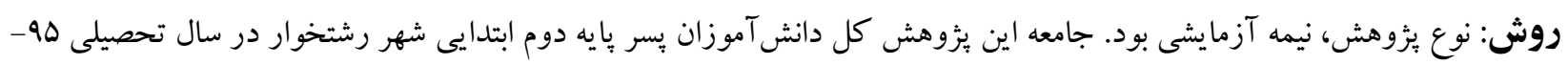

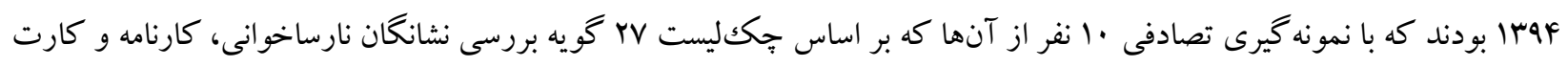

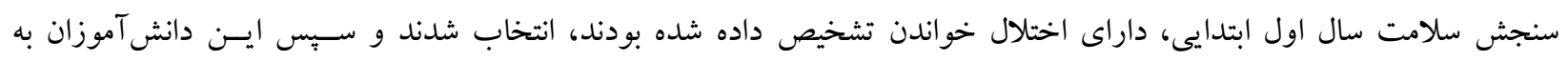

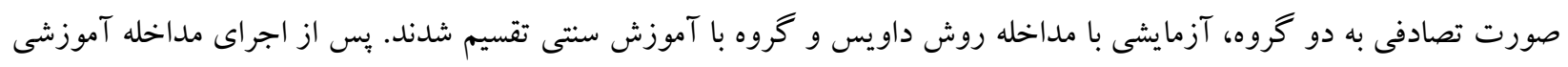

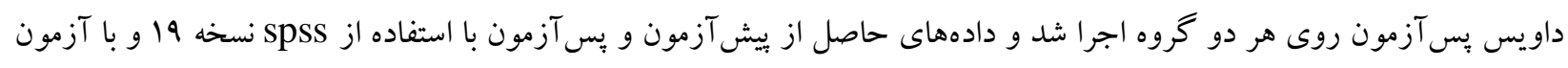

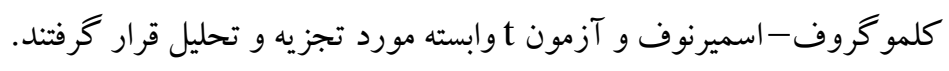

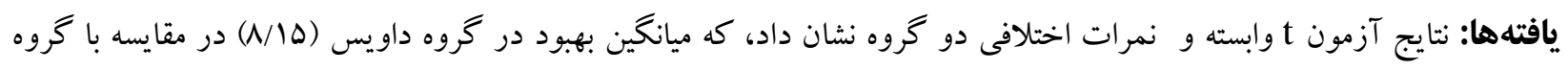

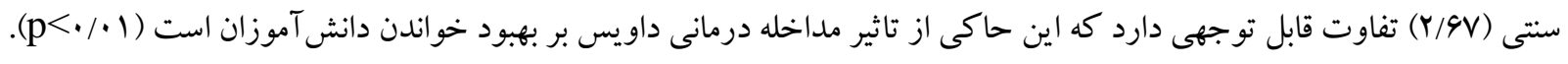
نتيجه كيرى: مىتوان نتيجه گرفت كه روش داويس با افزايش دامنه دقت و توجه، بهبود حافظه ديدارى و دركك مطلب، باعث ييشرفت در مهارت خواندن دانش آموزان شده است. كليدوازهها: خواندن، نارساخو انى، روش داويس، روش سنى 
(تيمورى، رضايى، محمدزاده، \هس|). اين ضعف در

مهارتهاى شناختى باعث ضعف در مهارتهايى مثل خو اندن مىشود كه در اصطلاح نارساخوانى مى گويند كه

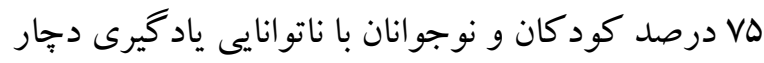

نارساخو انى هستند (محمد زاده و فرامرزى، لهوبا). اختلال خواندن در بنجمين ويرايش راهنماى تشخيصى و آمارى اختلالهاى روانى با علائمى همجِون كند، اشتباه، به سخنى خواندن كلمات، مشكل در دركك مطلب آنجه خوانده است و مشكلات در هجى كردن كلمات شناخته

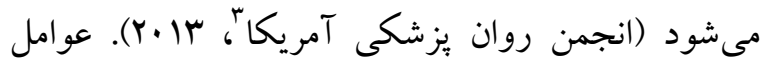
متعددى در شكل گيرى اختلال خواندن نقش دارد كه از آن جمله مىتوان به عوامل زنتيكى، عصبشناختى، شناختى و محيطى اشاره كرد (بيات مختارى، يوسفى، زارع، نجاتى، وهبr(). نارساخوانى به مشكلاتى در صحت و روانى خواندن و هجى كردن كلمات برمى گردد و در لهر بيشـتر مـوارد، نارسـاخوانى بـه وسيله نقـص ديــارى مشخص مىشـود (سياهكلرودى، عليزاده، كوشش، M IMM جشمى به مهارت درست خواندن دانش آموزان كمكك مى كند، در حالى كه دانش آموزان نارساخوان در سامانه ديدارى مشكلاتى دارند. بيشتر آنها تثبيت دوجشمى نايايدارى دارند و همين باعث مىشود تمركز كمترى روى وازگان داشته باشند و حروف را درهم بييند. همجنين عملكرد توجه انتخابى شنيدارى گوش راست و

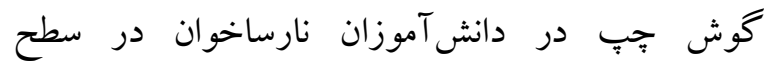
معنادارى يايينتر از كود كان عادى است (مؤمنى، ملكك-

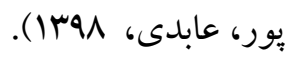

3- American Psychiatric Association
مقدمه

خواندن يكى از فعاليتهاى بسيار هوشمندانهاى است كه

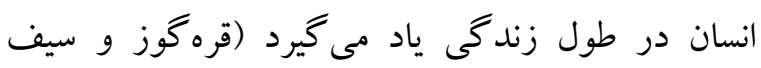
نراقى، INAV و در ميان مهارتها و اكتسابهاى آموزشگاهى در سالهاى اول مدرسه، از اهميت ويزهاى برخوردار است؛ اما علىرغم اهميت آن، كم نيستند كود كانى كه بيشرفت خواندن آنها در مقايسه با سن تقويمى، هوش اندازهيرى شده و ميزان آموزش فرد به طور قابل ملاحظهاى يائين تر از سطح مورد انتظار است (اهرمى، شوشترى، كلشنى و كمرزين، •وبا). ناتوانىهاى ياد گيرى را به عنوان يكى عامل روانشناختى لهنى كه مانع بيشرفت تحصيلى كودك در مدرسه مىشود تعريف كردهاند (كاربالالمارينو، گاكو آزيتوس، آرس آلوارز، دل ريو گارما، گارسيا كندون، گويكوئه كاستانو،

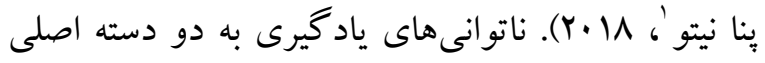
تقسيم مىشوند: ناتوانىهاى ياد گيرى تحولى و ناتوانى هاى ياد كيرى تحصيلى (اهرمى و همكاران، .وسم).

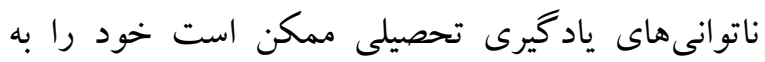
صورت اختلال در خواندن، نوشتن، رياضى، سخن كفتن، كوش دادن و فكر كردن نشان دهد (يترز، اسميت، كاسل، هاكان، مكى، ون متر، بريسنو، رايان، ولدون،

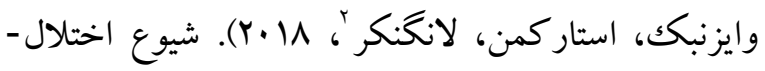
هاى ياد گيرى خاص حدود ها -ه درصد كود كان ابتدايى

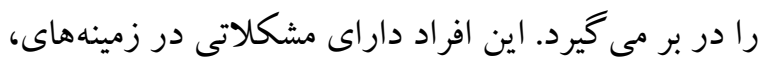
حافظه ديدارى و شنيدارى، هماهنكى ديدارى-حر كتى، سبك ياد گيرى، بيشفعالى و بىقرارى هستند كه ييشرفت تحصيلى آنها كمتر از سطح هوشى و سن آنهاست

1- Carballal Marino, Gago Ageitos, Ares Alvarez, Del Rio Garma, Garcia Cendon, Goicoechea Castano, Pena Nieto

${ }^{2}$ - Peters, Smith, Kassel, Hagan, Maki, Van Meter, Briceno, Ryan, Weldon, Weisenbach, Starkman, Langenecker 
تحصيلى كودكان بـه مراتـب تـأثير بيشترى نسبت به

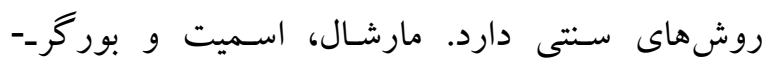

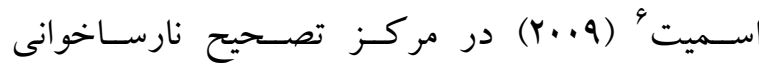
ديويس در كانادا بيش از •وس درمانجو را تحت بررسى قرار دادند. نتايج نشان داد كه اين افراد بيشـفتهــيى را در همه جهار سطوح خواندن (خواندن كلمات، قافيههـا، دركى كلمسه و دركك مستن) بـه دسـت آوردهانـد. همجِنين در بررسى سـطح بيشرفت افراد با توجه به سن، كود كان ^ متا Y I سـاله يشـرفت بالاترى را نسبت به ساير

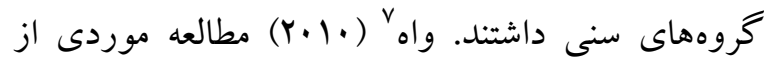
روش تصحيح نارساخوانى داويس را بر روى كودكى انجام داد. او گزارش داد كـه ايسن كـودك توانسـت بـا موفقيت نقطه موقعيتيابى داويس را براى كنترل كار كرد ذهـنش به كار ببرد. همجِنين تسلط بر نشانهاى داويس به او در معكوس كردن حروف كمكك كرد، تمرينهاى خواندن داويس نيز بـه او كمكك كرد تا عادتش را از جهيدن در حين خواندن تغيير دهد. از آنجا كه در خصوص تأثير روش داويس بر بهبود خو اندن دانش آموزان، يُزوهشهاى داخلى اندكى انجام شده بود؛ بنابراين هدف ئزوهش حاضر، مقايسه تأثير راهبرد آموزشى داويس با آموزش سنتى در بهبود

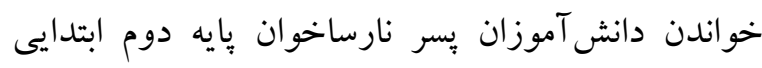

روش طرح بثزوهش حاضر از نوع نيمها آزمايشى شامل بيش آزمون-يس آزمون با گروه كنترل بود و جامعهى آمارى را كليه دانش آموزان يّر پايهى دوم دبستان شهرستان

6- Marshall-Smith \& Borger-Smith

7-Wah
داويس بيان كرد افراد نارساخوان گم گشتخى را تجربه مى كنند و اين امر به ادراكك تحريف شدهو اشتباههايى در خواندن و هجى كردن منجر مىشود. او آستانه گم كشتخى را عامل اصلى در اين سردر گمىها مىدانست

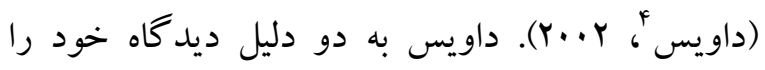
متفاوت مىداند؛ نخست اينكه بر ادراك تأكيد داشته دونه است و دوم اينكه جون خود فردى نارساخوان بوده، تجارب مستقيم و بعواسطهاى از اين حالت داشته است. داويس بيان كرد كلماتى كه عينى تلقى مىشوند، مشكل كود كان نارساخوان نيست، بلكه مشكل در كلمات راه انداز است؛ زيرا كود كان نمىتواند معانى آن را تصور كنند. داويس سه مؤلفه را به وجودآورندهُ نشانهاى نارساخوانى مىداند: شيوه خاص تفكر (تفكر تصويرى)، توانايى طبيعى براى تحريف ادراكى (جابهجايى جشم ذهن) و شيوه خاص واكنش به اين تحريفها (داويس، .$(Y \cdot .9$

كالاهانه (1..... در مقايسه تأثير روش داويس با آموزش آموزش سنتى مدارس دريافت كودكانى كه بـا روش داويس آمـوزش ديده بودند، در برنامـه خوانـدن

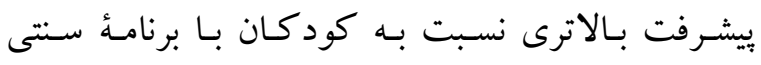
داشـتند و بـا مداخله روش داويس مهارت هـاى تحصـيلى

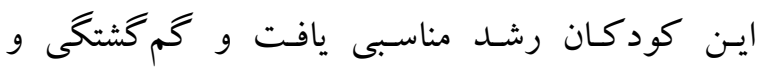
تحريف در ادراكك خواندن و نوشتن آنـان نيـز از بين رفت. نتايج يزوهش فيضى يور و اخـوانتفتى (IMAF) بـر روى F دانش آموز پيايه جهارم شهرستان اروميـه در مقايسه تطبيقى سطح اثربخشى روش داويس با شيوههاى

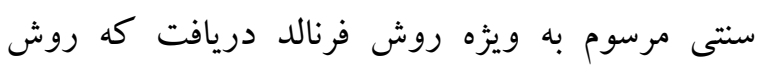
داويس در افزايش سطح مهارت خواندن و يِيشرفت

\footnotetext{
${ }^{4}$ - Davis

5 - Callahan
} 
سبس گروه آزمايشى به مدت · اجلسه و در هر هفته يكك تا دو جلسه ·r دقيقهاى آموزش خاص خود راد دريافت نمود كه خلاصهى جلسات آموزش به روش داويس در جدول شمارها آمده است و كروه كنترل(سنتى) غير از آموزش مرسـوم مدرسـهاى آموزش خاص ديخرى

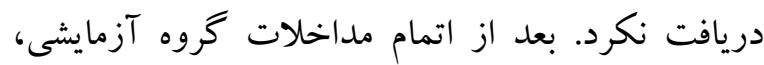
يس آزمون روى هر دو گروه اجرا شد و دادههاى حاصل از بيش آزمون و يس آزمون با استفاده از spss نسخه 19 و و با آزمون كلمو كروف اسميرنوف و آزمون t وابسته مورد تجزيه و تحليل قرار كرفتند.
رشتخوار در سال تحصيلى هوسا - Far| تشكيل دادند. از

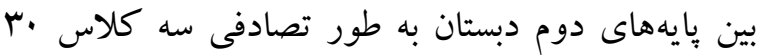
نفره انتخاب شد و از بين ها نفر از دانش آموزانى كه بر اساس روخوانى كتاب درسى، كارنامه، كارت سنجش

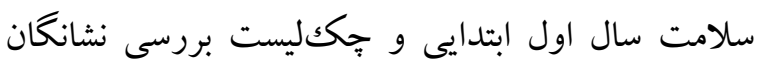
نارساخوانى، داراى اختلال خواندن تشخيص داده شده بودند، بهطور تصادفى ·ل نفر را انتخاب كرديم سـيس ايسن دانش آموزان به صورت تصادفى به دو گروه، آزمايشى(با مداخله روش داويس) و كروه كنترل(سنتى)

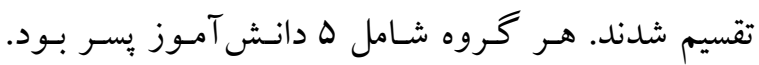

جدول ا خلاصهى جلسات آموزشى به روش داويس

\begin{tabular}{|c|c|}
\hline محتواى جلسات & جلسه \\
\hline تمرينات تمركز، برت كردن حواس و دوباره تمر كز روى محر كك مدنظر. & 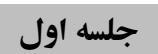 \\
\hline رهاسازى: بستن جشم و تصويرسازى بر خلاف آنجه در اطراف رخ مى دهد. & 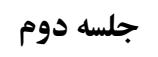 \\
\hline تمرينات موقعيت يابى يا جهت يابى: با جشم بسته مكان اشيا را بيدا مى كرد و تمرينات مشابه. & 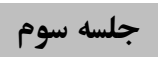 \\
\hline تمر كز روى نقطهاى و تعادل روى يكك پيا و تمر ينات مشابه & جلسه جهارم \\
\hline 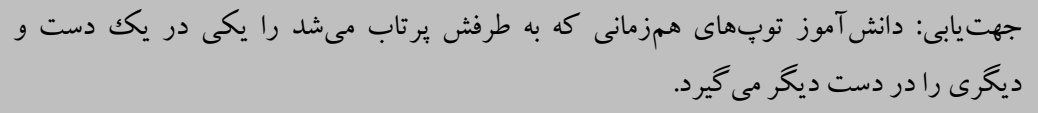 & 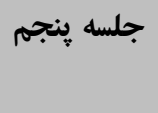 \\
\hline 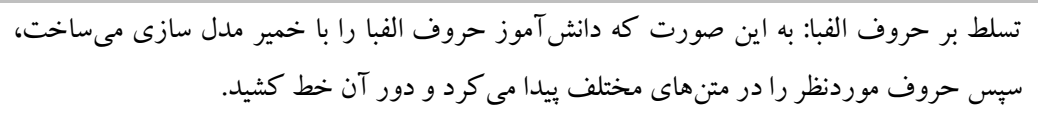 & 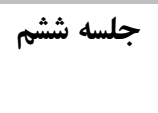 \\
\hline هميل بر بر نمادها: از دانش آموز خواسته مى شد علائمى مانند علامت سؤ ال، دو نقطه، وير كول و غيره & جلسه هفتم \\
\hline 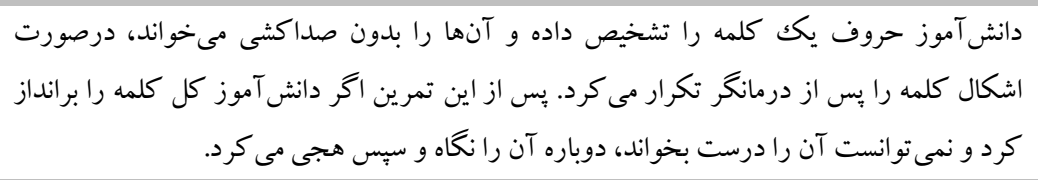 & جلسه هشتم \\
\hline 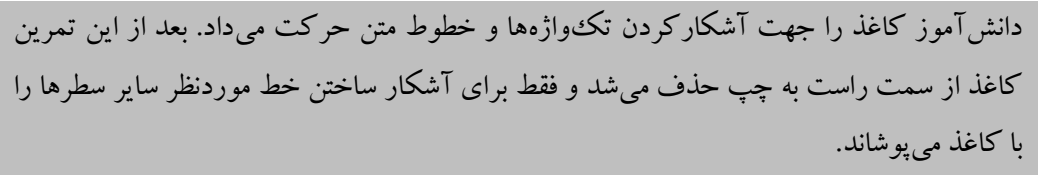 & جلسه نهم \\
\hline 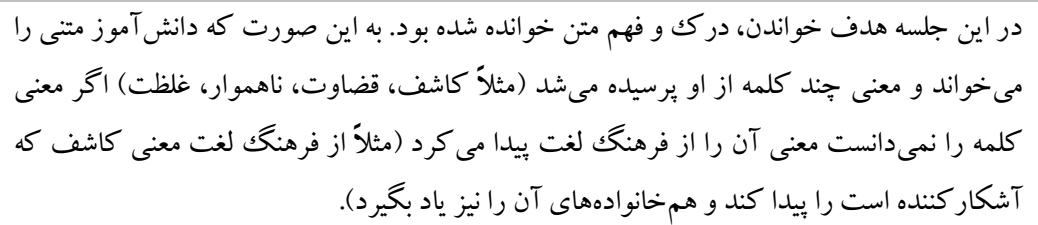 & 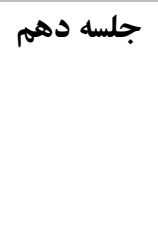 \\
\hline
\end{tabular}


متخصـص شــاغل در مراكـز نـاتوانىهــاى يــادگيرى

كــه در رابطـه بــا شناسـايى و درمـان نارساخوانها

جك إك ليست بروســى نشـانتان نارسـاخوانى: براى

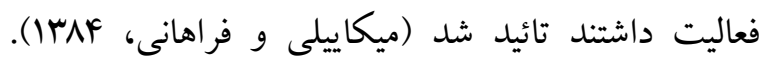
شناسايى دانش آموزان نارساخوان از جـك ليست بررسـى همجنين روايى محتو ايى برسشـنامه توسط اسـاتيد

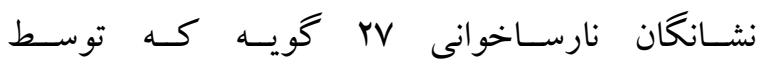

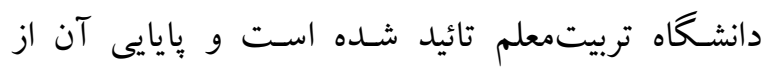

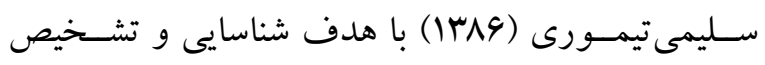
طريق آلفاى كرونباخ بالاى •V/\% ذكر شده است (سليمىدانش آموزان مقطع ابتدايى كه در معرض خطر ابتلا بـه

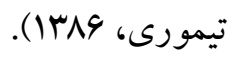
نـاتوانى و مشـكلات خوانـدن هستـند، استفاده شد. ايـن يرسشـنامه فرم معلـم بوده كه بايد توسط معلم بـا توجـه

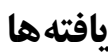

مطالعه حاضر را ·ـ نفر از دانش آموزان بِر نازساخوان پايه دوم دبستان در سال تحصيلى 9ه-هذ تشكيل داده بودند. يافتهاى توصيفى شامل ميانگين و انحراف معيار

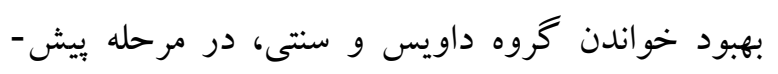
آزمون، يس آزمون در جدول شماره r آورده شده است. بـهـ شـناختى كـه از دانش آموز دارد در يسيش آزمسون و بسس آزمون تكميل و ارزيابى شود. نمره گذارى برسشنامه به صورت بلى و خير است. جهت بررسى خايسيى ايسن

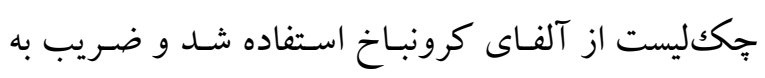

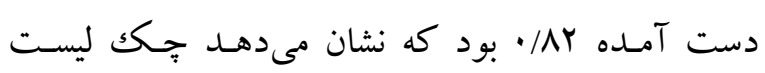

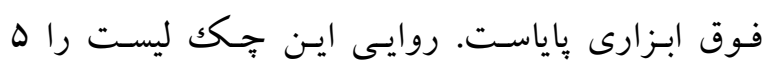

\begin{tabular}{|c|c|c|c|c|}
\hline انحر اف معيار & ميانكين & تعداد & زمان & بهبود خواندن \\
\hline$r / 9$. & $\Delta / F \Lambda$ & $\Delta$ & يِش آزمون & كروه آموزش به \\
\hline $1 / \wedge 9$ & (r/9r & $\Delta$ & پֶ آزمون & روش داويس \\
\hline r & $1 / 10$ & $\Delta$ & يِيش آزمون & \multirow{2}{*}{ كروه سنتى } \\
\hline$r / \Delta$ & $1 \cdot / A r$ & $\Delta$ & پِ پِ آزمون & \\
\hline
\end{tabular}

گروه سنتى تفاوت قابل ملاحظهاى با هم ندارند. براى بررسى نرمال بودن مفروضه از آزمون كلمو گروف-

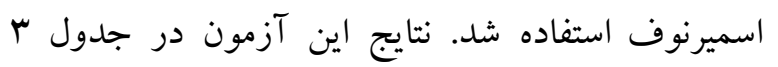
كزارش شده است.
نتايج آمارههاى توصيفى نشان مىدهد ميانخين بس آزمون

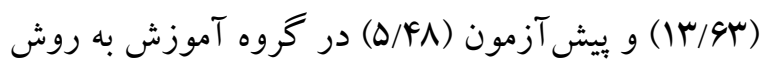
داويس تفاوت قابل ملاحظهاى با هم دارد. در حالى كه

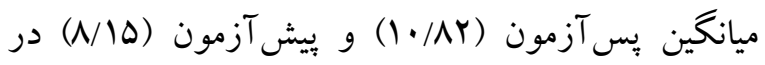

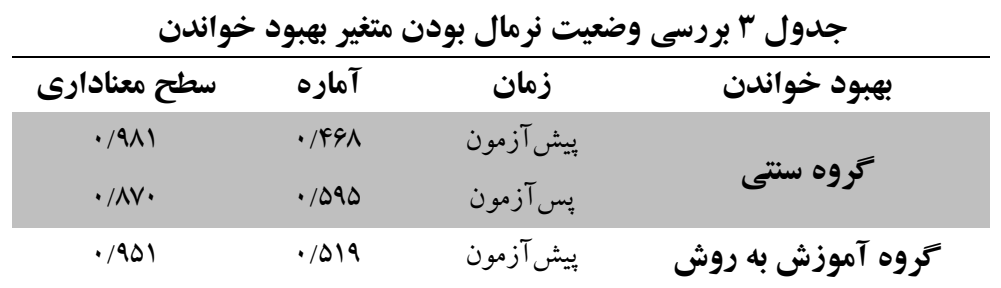




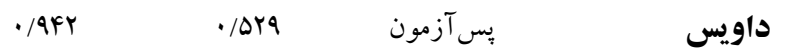

t t نتايج جدول شماره س نشان مىدهد كه توزيع نمرات در دو گروه داويس و سنتى نرمال است. براى بررسى تأثير استفاده شد و نتايج در جدول شماره ع ارائه شده است. آموزش به روش داويس و روش سنتى بر بهبود خواندن

جدول ع نتايج آزمون t وابسته بواى دو كروه

\begin{tabular}{|c|c|c|c|c|c|}
\hline سطح معنادارى & درجه آزادى & آزمون تى & انحراف معيار & ميانكين & \\
\hline$\cdot / \cdot 1$ & $f$ & $9 / 99$ & $r / V Y$ & $1 / 10$ & يش \\
\hline$\cdot / \cdot 1$ & $f$ & 9 & .194 & T/VG & يش \\
\hline
\end{tabular}

هدف اين يثزوهش بررسى و مقايسه اثربخشى راهبرد آموزشى داويس و آموزش سنتى بـر بيشرفت مهارتهاى خواندن و دركك مطلب دانش آموزان نارساخوان بود. يافتـهــاى يـرّوهش حاصل از آزمون T وابسته نشـان داد كه آموزش داويس در افزايش مهـارت خوانـدن دانش -

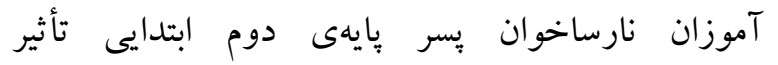
قابلتوجهى نسبت به آموزش سنتى دارد كه اين با يافته هاى مختلفى همسو است. به عنوان مثال؛ نتايج

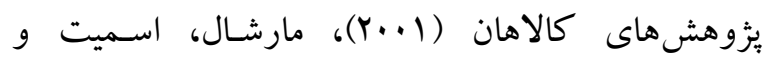

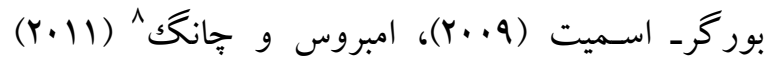
حاكى از اثربخش بودن روش داويس در درمان

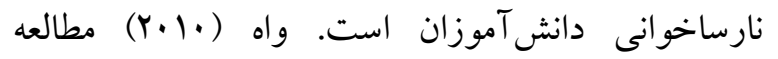
موردى از روش تصحيح نارساخوانى داويس را بر روى كودكى انجام داد. او گز ارش داد كـه تسلط بر نشانههاى داويس به او در معكوس كردن حروف كمكك كرد و عادتش را از جهيدن در حين خواندن تغيير داد. لاىواله

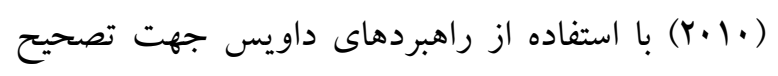

نتايج جدول f نشان ميدهد كه آموزش به روش داويس در سطح معنادارى (1 ( 1 ( $)$ بر بهبود خواندن دانش آموزان يايه دوم دبستان مؤثر است؛ بنابراين، نتايج حاكى از اين است كه آموزش به روش داويس موجب بهبود خواندن در دانش آموزان يسر نارساخوان يُايه دوم دبستان شده است. نتايج جدول \& همجنين نشان مىدهد كه آموزش سنتى در سطح معنادارى (1 ( > > ) نيز بر بهبود خواندن دانش آموزان يايه دوم دبستان مؤثر است؛ بنابراين، نتايج حاكى از اين است كه آموزش سنتى نيز موجب بهبود خواندن در دانش آموزان نارساخوان يايه دوم دبستان شده است. همجنين مقايسه ميانگين هاى اختلافى دو گروه، كواه بر اين است كه بين گروه آموزش به روش داويس (ه//ه) در مقايسه با كروه آموزش سنتى (Y/9V) تفاوت معنادارى وجود دارد كه با مقايسه ميانگين نمرات دو كروه مشخص مىشود كه كروه آموزش به روش داويس در بهبود خواندن دانش آموزان نارساخوان مؤثرتر بوده است. 
اغتشاش ادراكك تأكيد دارد و در بهتر خواندن دانشآموزان نارساخوان مؤثر واقع شده است. اين شيوه به دليل به كارگيرى قوه خلاقيت فراگير، استفاده از راهبردهاى تصويرسازى از جذابيت بالايى برخوردار است و با استفاده از اين روش، يادگيرى همراه با دركك و فهم، جايگزين ياد گيرى مبتنى بر محفوظات مى گردد. مى ئوان

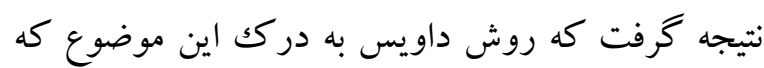
نارساخوانى به علت آسيب يا ضايعه مغزى نيست، بلكه يك نارسايى ادراكى است كمكك مى كند. كودكان نارساخوان مىتوانند ادراكهاى حسى خود را به صورت ناخودآكاه تغيير دهند و اين توانايى اغلب در رشد مهارتهاى تحصيلى مناسب، تأثير زيادى دارد.

\section{نتيجه كيرى}

با توجه به دادههاى به دست آمده مى توان نتيجه گرفت كه روش داويس با افزايش دامنه دقت و توجه، بهبود حافظه ديدارى، كلنخرى و درك مطلب، باعث بيشرفت در مهارت خواندن دانش آموزان شده است. از جمله محدوديتهاى يُزوهش حاضر، اجراى آن روى دانش - مهر آموزان يسر بوده و در تعميم نتايج روى دانش آموزان دختر بايد احتياط كرد. يِشنهاد مىشود در يزوهشهاى آتى از حجم نمونه بزرگكترى استفاده شود.

\section{سواسگزارى}

مقاله حاضر بخشى از باياننامه دوره ارشد به شماره كد

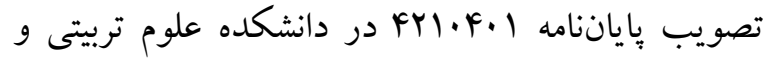
روانشناسى دانشگاه سمنان است. بدينوسيله از استاد راهنما و مشاور، رياست آموزش و يرورش رشتخوار و مدير مدرسه شهيد هاشمى و معلمان يايه دوم اين مدرسه
نشانه هاى نارساخوانى نشان داد مشاوره موقعيتيابى داويس در اصلاح مشكلات ادراك ديدارى و بهبود مهارتهاى خواندن و نوشتن و تسلط نمادين در بازشناسى و تصحيح وارونه سازى وازهها به كودكان نارساخوان كمك مى كند و همجنين نتايج يُوهش فيضى

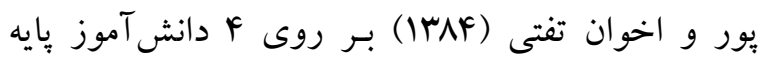
جهارم شهرستان اروميـه در مقايسه تطبيقى سطح اثربخشى روش داويس با شيوههاى سنتى مرسوم به ويزه روش فرنالد دريافت كه روش داويس در افزايش سطح مهارت خواندن و بيشرفت تحصيلى كود كان بـه مراتـب تـأثير بيشترى نسبت به روشهـاى سـنتى دارد. نتايج

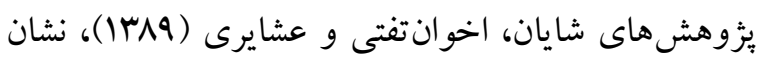
مىدهد آموزش تصحيح نارساخوانى داويس باعث بهبود خواندن بزركسالان مىشود. نتايج يزوهش حيدرى، شاه

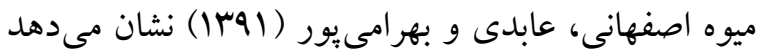
كه تمرينهاى داويس با تأكيد بر جنبههاى اساسى خو اندن كه شامل حركت جشم در سطح وازه، ديدن وازه به صورت كل، شناسايى حروف مجزا به دنبال هم به صورت يكهارجه، موجب بهبودى دانش آموزان در خرده مقياسهاى خواندن وازهها و زنجيره وازهها شده است. همجنين يزّوهش هاى خدا مهرى و همكاران (هوس (1)،

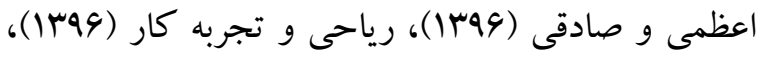

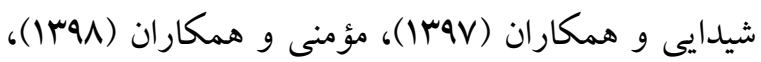

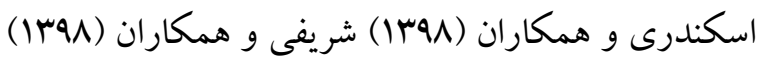
نشان مىدهند كه روش آموزش داويس بر بهبود خواندن دانش آموزان نارساخوان مؤثر بوده است كه نتايج اين يُزوهش ها با يافتهاى بثزوهش حاضر همسو است. در كل روش داويس بر شناخت و خواندن كلمات به صورت كلى، حفظ توجه، جلو گيرى از حواسبرتى و 
Psiquiatria Infantil de la Asociacion Galega de Pediatría de Atención Primaria (AGAPap). Prevalence of neurodevelopmental, behavioural and learning disorders in pediatric primary care. Anales de Pediatría (English Edition), in press, corrected proof, Available online 24 July 2018. 89(3), 153-161.

Davis KD. (2002). The gift of dyslexia. California: AbilityWorkshop Press.

Davis RD. (2006). Davis Dyslexia Association International. Positive aspects of dyslexia. Retrieved December 11, 2007 from http://www.dyslexia.com/qagitt.htm.

Eskandari S, Kakabarai K, Hosseini SA, Amiri H. (2020). The effectiveness of Davis teaching on improving reading skills, planning and organizing students with learning disabilities. Empowerment of Exceptional Children, 10 (3), 45-54. (In Persian)

Faizipour H, Akhavan Tafti M. (2005). Investigating the Effect of Dissatisfaction Correction Method on Increasing Reading Skills. (In Persian)

Heydari T, Shah Miwe Esfahani A, Abedi A, Bahramipour M. (2012). Comparison of the effectiveness of Fernald's and Davis' method on reading performance of dyslexic students. (In Persian)

Khodamehri F, Masouleh SM, Khosrow Javed M, Fallahi M. (2015). The effectiveness ofDavis's dyslexia correction method on the reading performance of male students with dyslexia. Quarterly Journal of Child Psychological Transformation - the period 2, Number 1. (In Persian)

Khoshroo M, Rezaei MA, Taleh Pasand S. (2016). Investigating the effect of phonological awareness and Davis on improving the reading of second grade dyslexic students, M.Sc. Thesis, Semnan University. (InPersian)

Lay Wahl L. (2010). The Davis Model of Dyslexia Intervention: lessons from one child school of educational studies, 18, 133-139.

Marshall A, Smith L, Borger-Smith S. (2009). Davis Program Average Reading Gains. RetrievedJune 26, 2010 from Dyslexia, the

$$
\begin{aligned}
& \text { كه ما را در انجام اين بيزوهش يارى نمودند، صميمانه } \\
& \text { تشكر مىنمايم. }
\end{aligned}
$$

\section{References}

Ahromi R, Shushtari M, Golshani Manzeh F, Kamarzin H. (2011). Effectiveness of teaching accuracy on the ability to read dyslexic female students in the third grade of elementary school in Isfahan. (InPersian)

Ambrose PP, Chong LS. (2011). Effects of Clay Modeling Program on The Reading Behavior of Children with dyslexia: A Malaysian Case Stady. The Asia- Pacific Education Research. 23(3), 999-993.

American Psychiatric Association. (2013). Diagnostic and statistical manualof mental disorders. Washington DC: American PsychiatricAssociation.

Azami E, Haj Sadeghi Z. (2017). Comparison of the effectiveness of neurofeedback and Davis treatment methods on dyslexic student reading performance. Zanko Journal of Medical Sciences, 18 (58), 1-14. (InPersian)

Bahari Qaregoz A, Seif Naraghi M. (2008). The effectiveness of Sinai training in reducing reading errors in dyslexic children. Journal of Psychology of Inadequacy, (16)‘ pp. 353-343.. (InPersian)

Bayat Mokhtari L, Yousefi AR, Zare H, Nejati V. (2018). The effect of direct electrical electrical stimulation of the brain on the skull and cognitive and cognitive training on improving the auditory function of dyslexic children's working memory. Journal of Exceptional Children, 17 (4), 37-48. (In Persian)

Callahan RT. (2002). A multidimensional approach to dyslexia: Does locus of control and selfesteem increase with a perceived increase in reading skills. Dissertation Abstracts International.

Carballal Marino M, Gago Ageitos A, Ares Alvarez J, Del Rio Garma M, Garcia Cendon C, Goicoechea Castano A, Pena Nieto J. (2018). En representación del Grupo de Trabajo de 


\section{Gift.URL:}

http://www.dyslexia.com/science/results.htm

Mikaili Manie F, Farahani MN. (2005). Investigating the phonological phonological processing model of reading in normal and dyslexic primary school students. Research in the field of exceptional children: the period 5, Number 4(Sequence 18); Pp 379-416. (In Persian)

Mohammadzadeh A, Faramarzi S. (2019). The effectiveness of monogamous awareness training through play on the dyslexia of people with special learning disabilities. Linguistics, 11 (32), 7-26. (In Persian)

Momeni Shahraki F, Malekpour M, Abedi A, Faramarzi S. (2018). Comparison of the effectiveness of psychological neurological interventions and Davis method on reading performance of dyslexic first and second grade elementary school students. Journal of Psychological Neurology, 4 (12), 153-174. (In Persian)

Peters AT, Smith RA, Kassel MT, Hagan M, Maki P, Van Meter A, Briceno EM, Ryan KA, Weldon AL, Weisenbach SL, Starkman MN, Langenecker SA. (2018). A pilot investigation of differential neuroendocrine associations with fronto-limbic activation during semantically-cued list learning in mood disorders. Journal of Affective Disorders. 239(3), 180-191.

Salimi Teymouri B. (2008). Investigation of the effect of Delacato's neuromuscular therapy on the developmental dyslexia of female elementary school students in Boroujerd city in the academic year of 2006-2008. Master Thesis Teacher Training University of Tehran, 2007. p 106. (In Persian)

Samhsiahkordi L, Alizadeh H, Kooshesh M. (2009). The effect of visual perception skills training on improving reading performance in dyslexic students. Cognitive Science News, 11, (2). Pp 63-72. (InPersian)

Sharifi A, Alizadeh H, Ghobari Bonab B, Farokhi NA. (2019). Comparison of the performance profile of children with dysfunction / attention deficit / hyperactivity disorder and children with special learning disabilities compared to normal children: with emphasis on the lack of comelation between the two disorders. Empowerment of Exceptional Children, 10 (1), 28-44. (In Persian)

Shayan N, Akhavan Tafti M, Ashayeri H. (2010). The effect of Davis repair method on improving adult dyslexia. (In Persian)

Sheydaie Firoozabadi T, Tajrobekar M, Tohidi A. (2018). The effect of Davis teaching method on reading skills and creativity of dyslexic students. Child Mental Health (2) 5, 180 170. (In Persian)

Tajmir Riahi R, Tajrobekar M. (2017). Comparison of the effectiveness of Davis method by combining two methods of Davis and Sina on improving the reading performance of dyslexic female students. Joumal of Disability Studies (Scientific-Research), 7, 91-91. (In Persian)

Teymouri L, Rezaei A, Mohammadzadeh A. (2020). Comparison of hope, motivation for academic achievement and academic self-concept in students with and without special learning disabilities. Learning Disabilities, 9 (2), 7-35. (InPersian)

Wah LL. (2010). The davis Model of dyslexia Intervention: Lessons from one child. Editorial Board. 